\title{
POETRY IN ACTION: VERSE AND NARRATION IN EVERYDAY COMMUNICATION
}

\author{
Robin Gwyndaf
}

\begin{abstract}
This paper considers the rich vein of less formal, mostly unofficial poetry, referred to as folk poetry and poetry in action, composed by bards and rhymesters in Wales, $c$. 1870-2005, and inspired particularly by everyday events and incidents within their own communities. In discussing the nature of this folk poetry, seven factors are mentioned. i. It is a social activity. ii. It is an activity which belongs to all people. iii. It may relate to all aspects of life. iv. Its forms are very numerous and non-static. v. It is, in essence, an oral activity. vi. It communicates messages in a direct and colourful manner, with the emphasis on narration and communication. vii. Folk poetry is functional, applied poetry. The paper concludes by offering brief answers to two questions: $i$. What is the value of folk poetry activity to members of the community? ii. What is the value to the ethnologist of studying folk poetry?
\end{abstract}

Key words: communication, community, everyday life, folk poetry, narration and narrators, orality and aurality, poetry in action, poets and rhymesters, power poetry, Wales

Since the days of the earliest Welsh poets, Aneirin and Taliesin, in the sixth century, no country in Europe has accorded the poet greater status than Wales (Davies 1993; Humphreys 1983; Parry 1955; Stephens 1998). Today you may be able to buy in craft and souvenir shops a beautifully printed card, or a hand-written framed anonymous quotation, which reads (in the English version): "To be born Welsh is to be born privileged, not with a silver spoon in your mouth, but with music in your blood and poetry in your soul." Is this rather romantic statement merely a myth, or does it have an element of truth in it?

One thing is certain: there was - and there still is - in Wales, particularly among the Welsh-speaking population, a deep and widespread interest in poetry. At the very beginning, therefore, I should like to present the thesis that no meaningful statement can be made about the nature of Welsh identity (or, indeed, the identity of any people), without a proper understanding of what I would call 'the allembracing power of creativity' - people's natural instinct and desire to express themselves in the most memorable, effective and interesting manner possible, whatever the form, be it verbal art: a saying or a proverb, a verse, a song, a story, or any form of visual art.

In this paper I confine my remarks to the rich vein of less formal, mostly unofficial poetry which we may call folk poetry, composed by numerous bards and rhymesters, and inspired particularly by everyday events and incidents within their own communities. Or, I may add, by individuals with strong creative instincts who are keen to make use of folk poetry for marketing and promotional purposes. 
The central questions asked are: why and how did people make such constant use of a variety of verse forms as a vital means of communication in their daily lives? Why do they continue to do so in the twenty first century?

Perhaps, we could re-phrase these questions and ask: why is verse (cante fable) sometimes used by storytellers in the middle of a tale, otherwise presented in prose? For example, in the medieval tales: the Second and Fourth Branches of the Mabinogi (Jones and Jones 1948) was verse in these narratives used merely for mnemonic purposes? Why in May 2005 did the Conservative Parliamentary Candidate for Cardiff West send the inhabitants of his constituency a card with these words boldly printed on it:

\section{Only the best For Cardiff West.}

Why use rhyme for such a declaration? And why did a coach company in Cardiff recently decide to advertise itself with these words clearly displayed on the side of its buses: Bws $i$ bawb o bobl y byd 'A bus for all the people of the world.' The Welsh words are a parody of a very well-known fourth and final line of an englyn by a nineteenth-century poet, Robert Williams, not to a bus, but to the Bible: Beibl $i$ bawb o bobl $y$ byd 'A Bible for all the people of the world.' An englyn is a 30 syllable stanza, composed in cynghanedd 'harmony', and based on an intricate system of repetition of consonants and the use of internal rhyme - an almost unique metrical phenomenon developed in Wales from about the ninth century onwards.

A partial answer to these and other relevant questions may be obtained by considering the nature of folk poetry itself. The verses yet to be quoted in this paper were composed roughly during the last 130 years and all refer to my own native rural district of Uwchaled, north Wales, an area situated between the towns of Bala and Ruthin, Corwen and Llanrwst. Let me briefly mention seven factors.

\section{FOLK POETRY, LIKE STORYTELLING, IS A SOCIAL ACTIVITY}

It is especially reflective of small, close-knit communities or, and I emphasize, a specific social group, such as quarrymen in former days at their caban (hut) during midday break, or children playing on school yards (Gwyndaf 1987-88; 1989). It is also an activity which belongs to both rural and urban communities and social groups. Furthermore new channels for transmitting the poetry continue to appear from one generation to the other. Today folk poetry may be displayed on notice-boards in offices, and use is made of such modern facilities as the radio, mobile phone, photostat machine, e-mail and the internet. 


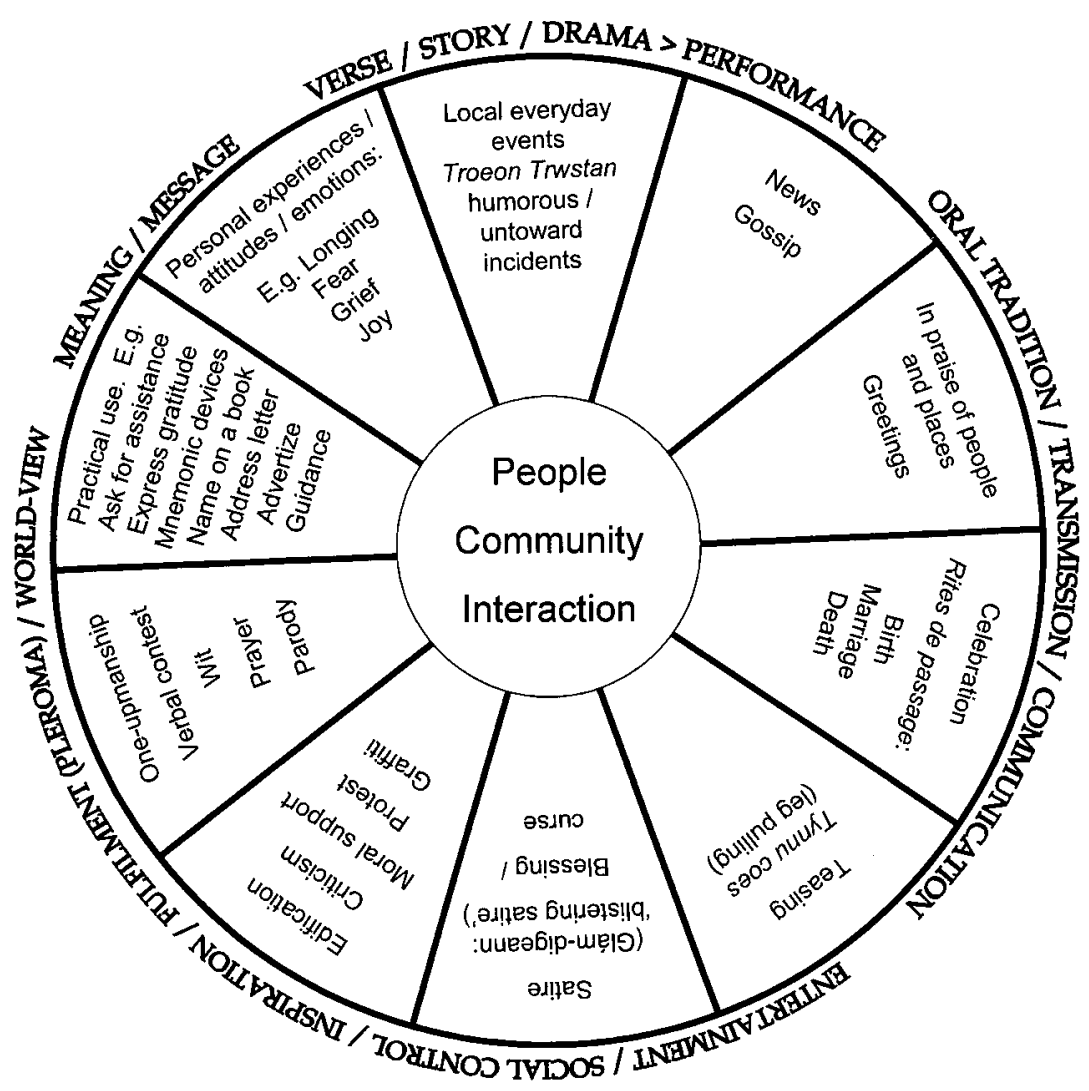

Figure 1. Poetry in action: verse and narration in everyday communication.

\section{FOLK POETRY IS AN ACTIVITY WHICH MAY BELONG TO ALL PEOPLE, ADULTS AND CHILDREN ALIKE}

No formal training is necessary. Ordinary people who would perhaps never venture to compose brand new poetry themselves can learn a whole poem, or parts of it, by heart and then, when repeating it can, if necessary, change a word, a phrase, or even a line, here and there to suit their own purposes. In Wales, as elsewhere, the urge to be recognised as the author of a few lines of poetry was very strong. It was an honour to be a poet and to have a bardic name.

Towards the end of the nineteenth century, there was a bardic contest in the Tavern of Bryntrillyn on the Hiraethog mountain. The task was to compose an englyn to the clock - an englyn, a four line stanza in the strict cynghanedd metre - quite a challenge. There were good poets present. But there also was John Jones, 
an illiterate (but not an uncultured) shepherd, mole catcher and rhymester. He too came forward with his own englyn which was not a proper englyn - simply a two-line couplet. But to him it was an englyn. He truly believed in his own creative powers, and he recited his "masterpiece" with fervour, much to the delight of all those present:

Ym Mryntrillyn mae cloc. In Bryntrillyn there is a clock.

Mae o'n mynd rwan, mi stopith toc! It's going now, it will soon stop!

\section{FOLK POETRY IS AN ACTIVITY WHICH RELATES TO ALL ASPECTS OF LIFE AND CIRCUMSTANCES - 'CANU'R BYD A'R BETWS' ('POETRY OF WORLD AND CHURCH').}

It relates the story of man o'r crud i'r bedd 'from cradle to the grave'.

\section{THE FORMS OF FOLK POETRY ARE VERY NUMEROUS, WIDE- RANGING AND NON-STATIC. THEY VARY ACCORDING TO CONTEXT AND FUNCTION.}

Often only parts of a poem or verse are remembered, used or adapted by people for specific purposes. The important factor, therefore, is not the specific genre used, whether the poem is long or short, or the particular method of transmission chosen, whether the poem is read, recited or sung. The important factor is: whether the form of folk poetry and the particular method of presentation chosen are the most appropriate for a specific occasion at a specific place and moment in time.

Folk poetry, like storytelling, is not a stagnant pool or a wide river flowing slowly on the lowlands, but rather a fast-flowing bubbling stream on the slopes and sometimes overflowing its banks. That is why the forms of folk poetry are nonstatic. Spontaneity, immediacy and creativity are important. For greetings, verbal contests, expressions of wit and one-upmanship, for example, a short rhyme or stanza is most suitable - just like a concise and lively dialogue in a drama. It is a dual activity and the greetings and responses are spontaneous. There is no time, or need, for a long deliberation. When, however, the poet relates some of the events and incidents in the lives of members of the community, or when he sings to celebrate birth, marriage or death, he takes a more leisurely approach and he will need a few more stanzas to present his story as fully and as interestingly as possible. On other occasions, for example, to tease, or to suggest satire, the use of parody can be very effective.

The boundary between prose and what we could call non-crystallised forms of verse can also, at times, be almost undistinguishable. Two friends who had not seen each other for many years greet one another:

"Well, how are you?"

“Oh, I'm married now." 
"Very good, very good"

"No, not so good, not so good, she was an old bitch!"

"Oh, very bad, very bad."

"No, not so bad, not so bad, I had a house with her."

"Oh, very good, very good."

"No, not so good, not so good, the house went on fire."

"Oh, very bad, very bad."

"No, not so bad, not so bad, the old bitch too burnt in the fire!"

Is it prose or is it poetry? Or does it matter?

To the scholar of folk poetry and folk narrative, therefore, the important factor to remember is not the particular form used: whether it is long or short, or whether it is prose or poetry, but whether that particular form used is a means to an end llawforwyn 'a hand-maid'. Whatever form chosen, it must be suitable, adaptable, memorable and repeatable.

\section{FOLK POETRY, IN ESSENCE, IS AN ORAL ACTIVITY}

Homo sapiens is a social creature. Communication with his fellow men and women is his life and soul. The early name for poetry in Welsh - a name still in use today - is cerdd dafod 'the art or craft of the tongue'. It follows that a good folk poet and storyteller secures a functional bridge between himself and the audience - whether it is an audience of one hundred or one person. It is a performance. The poems are to be enjoyed by others, in the words of an early chronicler: jocunde et memoriter 'with joy and from memory'.

The poet, as the storyteller, consciously and unconsciously, makes the best use possible of narrative techniques, learnt and inherited over many years, to ensure that his telling of the poems and stories is the most effective and memorable possible. There has to be a rapport between him and the audience: a dialogue; eye contact; body language (proxemics). The audience plays an active, not a passive, role. It is, to reaffirm what has already been suggested, a dual process of action and reaction; a dynamic, non-static activity. To understand the nature of folk poetry in action, therefore, due attention must be given to the study of aurality, that is, of the ear, as well as orality, the spoken word.

As in any literate society, many of the poems have either been written down by the poets themselves, or by interested listeners. And many poems have (and still are) published in local newspapers. Primarily, however, the poems are not intended to be read and published, but to be heard and repeated.

In any oral culture, memory plays a key role. One Welsh triad recorded in the sixteenth century in Pum Llyfr Cerddwriaeth (The Five Books of Poetry) states that: "Three things pertain to the poet: poetry, memory, and cyfarwyddyd" ("traditional lore'). Ars memoria was an important aspect in the culture of the Middle Ages and, in particular, in the teaching of rhetoric. Essays were written to develop the art of learning by memory. Folk poets throughout the centuries have 
developed the art of ensuring that their verse was as memorable as possible. They made use of every mnemonic technique available to them, such as the use of rhyme and pattern, in assisting the listeners to memorize the verse.

\section{FOLK POETRY COMMUNICATES MESSAGES IN A DIRECT AND COLOURFUL MANNER.}

It visualizes the invisible. The abstract becomes concrete. Unlike the experience of reading written literature, the success of presenting oral poetry depends on an immediate appeal. That is why the poems are composed in a language which is clearly understood on the first hearing. It is the language of the people in their everyday life. One is reminded of the word 'prose', derived from the Latin prosa (and the adjective prorsus), meaning 'direct'. In a word, folk poetry is 'power poetry'.

The main object of poetry, according to the sixteenth-century poet Simwnt Fychan, was: creu melyster i'r glust ac o'r glust i'r galon 'to create harmony for the ear and from the ear to the heart'. Similarly, the aim of folk poets was to compose verse which when recited - even when read - would 'sing' in the listener's ears. Rhythm, beat, rhyme, assonance, alliteration, euphony are all of paramount importance.

The style is also warm, personal, conversational and inviting - as if the poet is sitting with us on the hearth in a joyous company of friends and acquaintances. It is no accident that the nineteenth-century poet Huw Jones, Pentrellyncymer, opens one of his longer poems with the invitation: Os neswch chi'n isel, cewch chydig o chwedel ... 'If you come closer you will hear a bit of a tale ...'. (This is a dramatic poem describing vividly what happened when some young men in the village of Pentrellyncymer tied a cat to the tail of a pony owned by Dafydd Elis y Bŵt as punishment for the pony's ill-fated journey to a nearby farm to eat hay.)

As in folk narratives, characters and incidents in folk poetry are not presented by means of a long-winded, philosophical description. The emphasis, rather, is on conciseness and single-stranded plots, on coherence, logic, pattern and symmetry, on story and drama. Indeed, the folk poet is, in essence, a storyteller and dramatist. His great challenge is to create in the minds of his audience concrete pictures from abstract concepts. As the camera in a film moves smoothly from scene to scene, so the narrator-poet uses words and phrases in verse forms, intonation, body language, and every means possible, to ensure that the listener is able to visualise each scene in as clear and chronological order as possible.

A conscious build-up towards a climax, or more than one climax, at the end of a verse or the complete poem, is also important - the jolt - the unexpected turn which gives the listener a sharp, sudden shock and a pleasant delight. Often the unexpected turn occurs in a very short stanza, as in the following example. The rhyme relates to a well-liked, but rather lazy, nineteenth-century tramp or beggar, Twm Poole, who was known to stay for a few weeks, or even a few months at a time in Uwchaled. 
Thomas Poole yn chwilio am waith Ac yn gweddïo ar Dduw na châi o ddim chwaith!

Thomas Poole searching for work -

but also praying to God that he would never find it!

\section{FOLK POETRY IS FUNCTIONAL, APPLIED POETRY; BARDDONIAETH AT IWS BOB DYDD 'POETRY FOR EVERYDAY USE'}

Folk poetry is not a fine princess in silk in her palace of ivory, but a fine maid in her purposeful day-to-day clothes, and always busy at work. Literary excellence is not, necessarily, the principal object. Folk poetry, rather, is everyday power poetry in action.

And that action is happening there and then, before the poet's very eyes.

Like the old cyfarwyddiaid (medieval storytellers and tradition-bearers), the Welsh poets played an important role as guardians and interpreters of history. Even so, the prime role of folk poets, in particular, was not as historians of the past, but as storytellers and playwrights of the present. Their main interest was in current news and events. Their poetry is a re-enactment of the everyday life of their people. The functions of folk poetry, therefore, are innumerable and reflect the complexities of society and the human experience, past and present. These functions include:

\section{i. Entertainment}

Whatever other functions the poems fulfilled, the poets were first and foremost first-class entertainers. They, for example, related in verse what is known in Welsh as troeon trwstan (lit. 'awkward or embarrassing incidents'). These are descriptions of some unfortunate, untoward and, usually, humorous incidents which have occurred to a member or members of the community. Someone hears about one of these troeon trwstan and relates it to others, until it spreads like a rumour and becomes common knowledge in the whole community, much to the delight of its members. For example, my own father, John Hugh Jones, Llangwm, composed a light-hearted poem in 1955 to a young farmer in the district whose car became stuck in the ditch near his home in the early hours one Sunday morning. He had been courting a girl from another district and had to wake a neighbouring farmer to ask for the loan of his tractor in order to pull the car out of the ditch. Wales is a country renowned for this type of popular, incidental poetry. Verse is included primarily for mnemonic purposes, but also to supplement, as it were, the apparent formless, fragmentary character of the anecdote and add to the element of performance and entertainment. Today the tradition is very much alive, particularly in close-knit Welsh-speaking communities, and the poems (usually without declaring the author's name) are often published in the fifty or more papurau bro (Welsh-language 'community newspapers'). 
Closely related to these troeon trwstan poems are the highly entertaining poems in which the prime function is to tease. Folk poets are experts in the subtle art of tynnu coes 'leg pulling'.

\section{ii. Practical use}

Here the emphasis is very much on poetry in action and on verse as power poetry. The various uses made of folk poetry are very numerous and include:

a. To spread news and gossip.

b. To advise and give guidance.

c. To congratulate, e.g. on birthdays.

d. To welcome, e.g. a family to a new home.

e. To ask for assistance. E.g. a rhymester from Cefn Brith, towards the end of the nineteenth century, wrote a rhyme in the account book of Robert Thomas, the tailor, begging him to come at once to make a pair of new trousers for him.

f. To serve as designation on an envelope, instead of a formal and usual address.

g. To denote ownership of a book - short rhymes written on the inside cover.

h. To advertise, e.g., in newspapers and on posters, T-shirts and plastic bags.

i. To influence and act as a kind of prayer.

j. To inspire and comfort. E.g. a saddler towards the end of the nineteenth century was having much difficulty in making a saddle. The poet-farmer Elias Jones, 'Llew Hiraethog', Pentrellyncymer, comes along, notices the saddler struggling, and there and then composes an englyn to inspire the craftsman to complete his work.

k. To express one-upmanship in a verbal contest. E.g. "Jack, the Postman", from Cerrigydrudion, Uwchaled, again towards the end of the nineteenth century, was greeted in Welsh in a two-line rhyme by a man who said: "I have heard from one or two people that "Jack, the Postman" is breeding lice". Jack replies, again in verse: "If what they say is true, you too will be before long!"

1. To give thanks and praise.

\section{iii. Expression of personal feelings and the deepest emotions of the human heart, such as joy, grief and longing, and the celebration of man's rites of passage: birth, marriage and death.}

The tradition of reciting verses to the new bride and groom at wedding feasts is still very popular. The long and very rich tradition of composing in memoriam poetry is also very much alive. Short stanzas in the traditional strict metre cynghanedd and in free verse are carved on gravestones, and short and longer poems are published in Welsh-language community papers. 


\section{iv. Edification, criticism and satire}

The poets at times were also preachers. Their verses were sermons in miniature. They celebrate the continuation of all which is praiseworthy and lasting. And their poems reflect man's deep desire to triumph in his constant struggle between good and evil - pride, for example. In the second half of the nineteenth century the poet John Davies, "Taliesin Hiraethog" (1841-1894), in one of his poems describes a young lady, Elin, from Pentrellyncymer, who was rather proud and snobbish. I translate: "Elin, yr Hafod, with her dazzling white hat is exactly as if she is carrying a garden on her head! Take care when you judge any person: you don't judge a lady by the hat she is wearing!"

\section{CONCLUSION}

To conclude, two questions remain to be asked. First: What is the value of folk poetry activity to members of the community? The following threefold answer may be suggested:

i. It offers them first-class entertainment.

ii. It helps to create social control and uphold standards.

iii. It is a means for members of the community to identify themselves with the joys and sorrows of their fellow inhabitants. In general, it usually brings people together. It fills a vacuum in people's lives. It is a shared activity. The poet communicates messages which are common to all. He contributes towards making life more meaningful. In short, he assists people to achieve that state of bliss: what the Greeks called pleroma: 'fulfilment'. To quote the poet T Gwynn Jones (1871-1949), in his couplet to the Llangollen International Musical Eisteddfod (1947):

Byd gwyn fydd byd a gano, Blessed is the world that sings,

Gwaraidd fydd ei gerddi fo. its songs are cultured

The second question is: What is the value to the ethnologist of studying folk poetry? Again, the following three answers are offered:

i. Although folk poetry fulfils a social, rather than a literary primary function, the student of literature will be pleasantly surprised to discover so many items which will give him also tremendous aesthetic pleasure.

ii. The more we know about the nature of folk poetry activity as one particular aspect of a community's culture, the more we will know also about the nature of the life of that community as a whole: people's work and recreation, fears and aspirations, their beliefs and customs. In short it opens a fascinating door to understand people's history, identity and world-view.

iii. An in-depth study of the folk poetry of any country will teach the scholar the importance of adopting a holistic approach to his subject. That is, not to be car- 
ried away by what the academic would call "genre-analysis", and to place his material in neatly-labelled little boxes: "this is a verse", "this is a narrative", and so forth. Rather the scholar should give equal emphasis on understanding how a wide range of forms are used, consciously and unconsciously, by people in their everyday life to communicate innumerable messages - messages which are universal to people in all corners of the world and at all times, past and present. Indeed, the more we know about the cultural activity of any one community in any one country - be it folk poetry, folk narrative, or any other form used - the more we will know also about the development of people's culture worldwide, through the ages.

\section{References}

Davies, John 1993. A History of Wales. London: Allen Lane.

Gwyndaf, Robin 1987-88. The Welsh Folk Narrative Tradition: Continuity and Adaptation. Folk Life, 26, pp. 78-100.

Gwyndaf, Robin 1989. Chwedlau Gwerin Cymru: Welsh Folk Tales. Cardiff: National Museum of Wales.

Humphreys, Emyr 1983. The Taliesin Tradition: A Quest for the Welsh Identity. London: Black Raven Press.

Jones, Gwyn \& Thomas Jones 1948. The Mabinogion. London: J. M. Dent, Everyman Edition.

Parry, Thomas 1955. A History of Welsh Literature. H. Idris Bell (tr. from the Welsh). Oxford: The Clarendon Press.

Stephens, Meic 1998. A New Companion to the Literature of Wales. Cardiff: University of Wales Press. 